\title{
FACTORS DETERMINING COMPETITIVENESS IN HEALTHCARE INSTITUTIONS IN LATVIA - RESULTS OF THE EKOSOC-LV NATIONAL RESEARCH PROGRAMME
}

\author{
Anita Villeruša\#, Daiga Behmane, Uldis Berḳis, Anita Kokarēviča, and Vinita Cauce \\ Rīga Stradiṇš University, 16 Dzirciema Str., Rīga, LV-1007, LATVIA \\ \# Corresponding author, anita.villerusa@rsu.lv
}

Communicated by Remigijs Počs

\begin{abstract}
Competitiveness as a factor of a company selling its services in the market is becoming more relevant in the healthcare sector. The number of institutions that offer their services to international patients is growing. Research shows that the development of medical tourism is countryspecific. The main objective of this publication is to discover positive and negative factors for engagement in the provision of services to non-residents. The data was obtained from a crosssectional study in which 86 managers of health care institutions in Latvia completed a questionnaire. A total of $80.2 \%$ of health care institutions had provided services to non-resident patients in the previous year while $19.8 \%$ did so regularly. Institutions mainly used websites to advertise their services. Only a small number of institutions employed a marketing specialist or had a strategy to attract non-resident patients. Heads of institutions pointed to a number of internal and external barriers in this connection, including lack of staff, low motivation, limited language skills, inadequate infrastructure, insufficient state-level support to promote the export of services, the social environment, and problems in the health system itself. The study revealed areas that need to be improved regarding future policies to attract non-resident patients and to increase global competitiveness.
\end{abstract}

Key words: competitiveness factors, health care institutions, non-resident patients, medical tourism.

\section{INTRODUCTION}

One of the areas of research of the National Research Programme 5.2. "Economic Transformation, Smart Growth, Governance and the Legal Framework for the Sustainable Development of the State and Society - New Approaches to Creation of Sustainable Knowledge Society (EKOSOCLV)" was to describe the competitiveness of Latvian companies in foreign markets and to make proposals for its development. Research on the competitiveness in the healthcare sector was conducted within this framework and the data on medical services provided to non-resident patients was collected and analysed. As a theoretical basis, Porter's Diamond Model was used. Competitiveness in the economy, business theory and practice is the ability of companies, industry or the state to sell their products, goods or services in the market. Consequently, competitiveness is one of the most important categories that characterises the markets of goods and services. Porter's Model looks at sev- eral elements of productivity, such as company strategy, structure, competition, production factors, demand and also supporting elements such as opportunities and national influences (Počs and Ozolina, 2016). The processes of globalisation have affected the supply and consumption of health services in a transnational context. The movement of patients to other countries to receive different health care services is now referred to as medical tourism or health tourism. It is developing globally as a new type of business and is an important business in some countries, combining tourism and health services to promote the well-being of people (Lee, 2007).

The General Agreement of Trade in Services (GATS) of the World Trade Organisation (WTO) has defined four types of health services. The definition is based on the territorial presence of supplier and consumer at the time a service is provided: both parties may reside in different places (mode 1 ), the consumer may have moved abroad into the country 
of the supplier (mode 2), the supplier may have established a branch, subsidiary, etc. in the consumer's territory (mode 3 ), or, in the case of private individuals, the supplier may be physically present (mode 4) (Adlund and Carzaniga, 2001). Medical tourism is more in line with the second mode within this study where non-residents move to Latvia to receive a service.

In the age of globalisation, medical tourism is becoming an increasingly important part of national health policies (Carrera and Bridges, 2006).

Traditionally, the flow of health service exports was from North to South, with patients travelling in the opposite direction. This situation is changing and the growth of health service exports from Southern countries is expanding now; the main flow of health tourism is increasing from rich and economically developed countries to economically less developed countries (Lautier, 2014).

The OECD public review regarding indicators of a health care system listed Latvia among the top ten countries with the largest export of healthcare services in Europe, accounting for $0.68 \%$ of total health care consumption in 2012 (Anonymous, 2014).

The rapid growth of medical tourism in recent years has been associated with a number of factors. This has been influenced by the increase in the costs of treatment in rich countries and long waiting lists, relatively cheap and easy travel and favourable exchange rates, as well as the availability of highly qualified doctors and medical professionals (Singh, 2013). The introduction of a visa-free regime in specific regions has also increased medical tourism; it has become a means of serving chronic and daily health needs through visa-free travel or inter-regional mobility (Ormond and Sulianti, 2017).

The free movement of patients between Member States of the European Union and Member States of the European Economic Area has also been facilitated by the EU Directive 2011/24 of the European Parliament and of the Council of 9 March 2011 on The Application of Patients' Rights in Cross-Border Healthcare (Anonymous, 2011). The All EU nationals and non-EU nationals and their families who are living legally inside the EU and EEZ have rights to be treated under the same rules, obligations and conditions as local residents of the country where a treatment is received. The Directive sets also requirements for national health care systems and providers to be capable to operate in an international environment. The Latvian health care system is based on general tax-financed statutory health care provision, with a purchaser-provider split and a mix of public and private providers.

One of the most important conditions for developing collaboration with patients outside Latvia is the ability of the host medical institution to measure its performance against certain criteria. Institutions that want to offer healthcare services to non-resident patients are registered with the
Health Inspectorate. Currently 47 medical institutions were registered for the provision of medical tourism services to patients outside Latvia (Anonymous, 2018).

The decision of a patient to receive healthcare abroad is also influenced by factors such as the language, the location of the country of destination, such as distance of travel, the political and religious situation, access to information on the provision of health care services and the possibility of combining health tourism with recreation (Crooks et al., 2010; Snyder et al., 2011). The decision of a non-resident customer can also be affected by the quality of medical products or services, effective communication, the level of satisfaction, costs and past experiences (Han and Hwang, 2018). It is much easier for a patient in an era of technological development to find a quality service in many countries and which can be obtained at a low cost and with no waiting. The development and availability of the Internet around the world is now seen as an important channel through which many medical tourism providers advertise themselves and sell their services (Johnston et al., 2012).

Factors such as the globalisation of health insurance companies and their efforts to reimburse customers for cheaper services, including those that are not included in the list of the home state-paid services or those that are not available in the home countries are also beneficial to the receipt of medical services in other countries.

Medical tourism is market driven - it is shaped by the complex interactions of myriad medical, economic, social and political forces (Mattoo and Rathindran, 2006).

Receiving services in another country or engaging with specialists from another country has also been made possible by the development of remote medicine or telemedicine. The developments of technologies suggest that there is great potential for rapid growth in this area. Some countries are also investing heavily in modern diagnostic and medical equipment. It is precisely the export of diagnostic procedures that is now one of the potential areas for medical exports. These medical exports are facilitated by International Cooperation Agreements. Medical travel has quickly transformed medical services into an internationally tradable commodity, with many countries vying for a share in this growing industry. Researchers predict that the international trade of medical services will continue to grow in the foreseeable future; first among neighbouring countries and countries within the same region (Timmermans, 2003; Anonymous, 2014).

Both country and individual institutions are competing in the international market; this requires careful consideration of the approaches to marketing and identifying the most suitable service to export. Often countries employ marketing professionals for this purpose. Professional marketing strategies are also increasingly used to shape the image of the exporting country or institution (Lunt and Carrera, 2011; Lee et al., 2012). Research done in other countries has also shown that professionals in the field need to make 
efforts to attract medical tourists. Health professionals need to possess good language skills, cross-cultural awareness and communication skills in addition to their professional knowledge to help to attract non-resident patients. Studies have suggested that one of the most important determinants of customer choice of service is the expectations of a patient or the perceived value of the service (Horowitz and Rosensweig, 2007; Wang, 2012). Consequently, the heads of health care institutions and state policy makers need to combine their efforts in promoting medical tourism for non-residents and make these services available.

Sources of literature from different countries indicate that information on the volume of medical tourism, its contributory factors, and the range of services is country-specific. This information has been obtained through quantitative or qualitative research. So far, little research has been done in Latvia to characterise medical tourism as a potential export commodity. There is also no routine tracking of types and the volume of services.

The aim of this study was to characterise the provision of health care services to non-resident patients in Latvia, as well as to identify factors that could contribute to or hinder medical exports that affect the competitiveness of health care services in the international market.

\section{MATERIALS AND METHODS}

Data was obtained from a cross-sectional study in which the subject of the study was health care institutions. A questionnaire was developed and tested by a team of researchers and was completed by the heads of health care institutions. The questionnaire had five parts: the first part provided general information on the health care institution and its involvement in the provision of services to patients outside Latvia; the second part included questions on promoting exports in the health care sector; the third part dealt with issues related to staff resources of the institution; the fourth part asked for possible and desirable forms of support for the export of health care services and the fifth part dealt with the procedural and environmental aspects that promoted or hampered the competitiveness of the healthcare institution.

The sample unit selected for the study was a health care institution, but not an individual medical practice. A list of health care institutions was obtained from the Register of Medical Institutions of Health Inspectorate. Taking into account the inclusion criteria, all national hospitals, all regional hospitals, all municipal hospitals, all private hospitals, outpatient institutions that do not have an individual medical practice and dental practices were selected and questionnaires were sent to the respective 230 institutions. Questionnaires were sent in several stages from June 2015 to January 2016. Eighty seven respondents (37.8\%) returned the questionnaires, of which $51.2 \%$ of the questionnaires returned came from private health care institutions, $32.1 \%$ were municipal institutions and $16.7 \%$ were national health care institutions. Inpatient medical treatment institutions ac- counted for $33.3 \%$, dental practices $29.8 \%$, health centres $19.0 \%$, day care centres $11.9 \%$, outpatient rehabilitation institutions $3.6 \%$ and $2.4 \%$ were doctors' practices and laboratories. Approximately a third of the institutions surveyed were from Rìga $-31.1 \%$, and $10.4 \%$ from the Rìga planning region, while the remainder came from the planning regions of Kurzeme - $16.9 \%$, Zemgale - $15.6 \%$, Vidzeme - 14.3\%), and Latgale - $11.7 \%$.

The provision of health care services to non-residents was used as a dependent variable in the analysis of data. The question "Does your institution currently provide services to non-resident patients/customers?" was used to determine the provision of services. The characteristics of service provision for non-residents related to personnel, the internal policies of the institution, such as the website of the institution, its strategy, service analysis, knowledge of the export market, participation in exhibitions, and the state policy such as regulatory support, health care system, specific support structures, and the social environment were used as independent variables.

Institutions were grouped into two categories for the calculation of odds ratio: those who provided services for nonresident patients and those that did not provide services of this kind. When personnel-related factors were analysed, both regular and non-regular providers were considered as healthcare institutions providing services to non-resident patients. In the analysis of internal and external factors that had an impact on attracting non-resident patients or medical tourism, the institutions in which non-resident patients were treated regularly were included in the category of providers. The second group consisted of medical institutions that did not provide services to non-residents. In order to carry out the Fisher's Exact test and calculate the odds ratio (OR) the categories of the answers "Yes, fully agree" and "Yes, partly", and the options of answers "More likely" and "Rather yes" were interpreted as "Yes". The options of the answers "Probably Not" and "No" were interpreted as "No".

Of all participants $(n=87), 86$ respondents were included in the analysis of the results.

Statistical analyses were performed using SPSS v. 22.0. Descriptive and analytical statistical methods were used for analysis of the data. The odds ratio (OR), the $\chi 2$ (Hi square) test and the Fischer Exact test were used to determine the relationships between the factors and service delivery to non-residents.

The results were considered statistically reliable if the $p$ value was less than $0.05(p<0.05)$. The $95 \%$ confidence interval $(95 \% \mathrm{CI})$ was used to estimate the parameter values.

\section{RESULTS}

Service provision to non-resident patients. In relation to the type of the institution, $92.9 \%(\mathrm{n}=26$; 95\% CI $77.4-$ 98.0) of inpatient treatment institutions, $81.2 \%(\mathrm{n}=13$; 
95\% CI 57.0-93.4) of health centres, $70.0 \%(\mathrm{n}=7 ; 95 \% \mathrm{CI}$ $39.7-89.2)$ of day care centres and $68.0 \%(n=17 ; 95 \%$ CI 48.4-82.8) of dental practices had provided services to non-residents in the previous year. Inpatient centres provided both regular and occasional services to non-residents more often than other institutions. Targeted (i.e. regular) healthcare services to foreigners were provided by approximately one fifth of the institutions surveyed, or $19.8 \%(\mathrm{n}=$ 17 ; $95 \%$ CI $12.7-29.4)$, but $60.4 \%(\mathrm{n}=52 ; 95 \%$ CI 50.0 70.1 ) only occasionally.

Outpatient and day care hospital services were the services used most frequently by non-resident patients: $56.0 \%(95 \%$ CI 45.3-66.1) of all institutions surveyed, followed by $51.2 \%$ for diagnostic services (95\% CI 40.7-61.6), dental services - 50.0\% (95\% CI 39.5-60.5) and rehabilitation services $46.4 \%$ (95\% CI 36.2-57.0). There was a direct correlation between the size of the health institution expressed in the numbers of staff and services provided to nonresidents. All large hospitals provided services to nonresident patients during the year in comparison to $84.2 \%$ of institutions who employed from 11 to 50 employees. However, for those institutions with up to 10 employees, only $60 \%$ provided services to non-residents during the year (95\% CI 40.7-76.6). 40\% of large clinics (over 500 employees) provided regular services and $60 \%$ of them provided occasional services to non-resident patients, while in institutions with fewer employees this number was smaller.

Geographic differences were evident in the provision of services to non-resident patients. All health care institutions in Rīga and the Rìga Planning Region provided services to non-residents and every third institution reported that this was a deliberate policy. Among the regions, the most frequent services to foreigners were provided in Zemgale (75.0\%) while the rates in Kurzeme, Vidzeme and Latgale were similar, i.e ranging from $55.0 \%$ to $62.0 \%$. Regular patients were attracted to surgical manipulations, including plastic surgery and minor cosmetology. In general, most services in health care institutions were provided to patients from nearby foreign countries, such as Russia 76.1\% (95\% CI $64.7-84.7 \%$ ), the United Kingdom $64.2 \%$ (95\% CI $52.2-74.6 \%$ ), Lithuania $49.3 \%$ (95\% CI 37.7-60.9\%), Norway $43.3 \%(95 \%$ CI $32.1-55.2 \%)$ and Germany $41.8 \%$; (95\% CI $30.7-53.7 \%$ ). But heads of institutions that provided services to foreign patients on a regular basis $(\mathrm{n}=$ 17 ), noted that the highest number of patients came from Sweden $45.0 \%$ (95\% CI 25.8-65.8\%), Finland $42.9 \%$ (95\% CI $21.4-67.4 \%$ ), and Belarus $41.7 \%$ (95\% CI $24.5-61.2 \%$ ).

Staff aspects. The survey identified certain aspects that characterised the staff, including staff provision, professionalism, work culture, competence development and its relevance to the provision of services to non-resident patients.

Among the respondents, most organisations stated that it was difficult to recruit doctors and nurses, respectively $71.8 \%(\mathrm{n}=61 ; 95 \%$ CI 61.4-80.2) and 70.2\% $(\mathrm{n}=59 ; 95 \%$ CI 59.8-79.0). Difficulties in finding support staff was also reported by $48.8 \%$ ( $\mathrm{n}=41 ; 95 \%$ CI $38.4-59.3)$ but only
$30.1 \%(\mathrm{n}=25 ; 95 \%$ CI 21.3-40.7) among administrative staff. Although statistically insignificant $(\chi 2=0.312$; df $=$ $1 ; p=0.576)$, it was reported that services were provided most frequently for non-residents in institutions where managers indicated that they had no problem with staff recruitment.

In total, 96.5\% ( $\mathrm{n}=83 ; 95 \%$ CI 90.2-98.8) heads of staff were satisfied with the professionalism and work culture of their staff. Heads of institutions in $81.8 \%$ cases $(n=63$; 95\% CI 71.8-88.9) indicated that the institution was interested in providing services to non-residents. It was also discovered, although statistically insignificant ( $p=0.107)$, that services to non-resident patients were provided most frequently at institutions whose managers noted that their employees were also interested in providing services to nonresidents, namely $88.9 \%$ ( $\mathrm{n}=56$; 95\% CI 78.8-94.5), compared to $71.4 \%(\mathrm{n}=10 ; 95 \% \mathrm{CI} 43.4-88.3)$ in the group where the staff of the institution were not specifically interested in providing services to non-resident patients. In those institutions where employees were interested in providing services, there was a 3.2 greater chance (95\% CI $0.8-13.0$ ) of providing healthcare to non-residents than in those whose staff were not interested. There were also differences between individual staff groups. Statistically significant relationships were found in doctors and administrative staff. It was also seen that the chances of providing services to non-residents increased by the interest of administrative staff in the provision of services (Table 1).

Heads of institutions identified the language barrier $78.6 \%$ (95\% CI 68.7-86.0) as the most important staffrelated problem in providing services to non-residents. Other problems identified were: heavy workload - 67.9\% (95\% CI 57.1-77.1) and lack of motivation to perform additional tasks - 39.8\% (95\% CI 29.9-50.5). Managers also admitted that staff were not psycho-emotionally prepared to

Table 1

ODDS RATIO FOR PROVIDING SERVICES FOR NON-RESIDENTS IN RELATION WITH FACTORS CHARACTERISING STAFF

\begin{tabular}{|c|c|c|}
\hline \multirow[t]{2}{*}{$\begin{array}{l}\text { Staff problems/factors identified } \\
\text { by the manager (Yes / No) }\end{array}$} & \multicolumn{2}{|c|}{$\begin{array}{c}\text { Provision of services to } \\
\text { non-resident patients } \\
\text { (Yes / No) }\end{array}$} \\
\hline & $\mathrm{OR}^{*}$ & $95 \% \mathrm{CI}$ \\
\hline $\begin{array}{l}\text { Doctors are interested in attracting foreign } \\
\text { patients }\end{array}$ & $3.4 *$ & $1.1-10.3$ \\
\hline $\begin{array}{l}\text { Nurses are interested in attracting foreign pa- } \\
\text { tients }\end{array}$ & 2.4 & $0.8-7.3$ \\
\hline $\begin{array}{l}\text { Administrative staff are interested in attract- } \\
\text { ing foreign patients }\end{array}$ & $5.1 *$ & $1.6-15.8$ \\
\hline $\begin{array}{l}\text { Psycho-emotional readiness to work with } \\
\text { non-resident clients }\end{array}$ & 1.9 & $0.5-6.6$ \\
\hline Language barrier & 1.2 & $0.3-4.1$ \\
\hline Lack of medical knowledge & 0.5 & $0.04-5.8$ \\
\hline Lack of motivation & 2.3 & $0.7-7.8$ \\
\hline Poor service culture & 1.2 & $0.3-5.0$ \\
\hline High workload & 1.8 & $0.6-5.8$ \\
\hline
\end{tabular}


work with non-resident patients - 35.9\% (95\% CI 26.2-47.0) and had a poor culture of services $21.5 \%(95 \%$ CI 13.9-31.8). Insufficient professionalism and medical knowledge was only identified as a barrier in $3.8 \%$ (95\% CI 1.3-10.6) cases.

The odds, although statistically insignificant, of providing services to non-resident customers was higher in institutions where managers were more likely to point to staff-related problems (Table 1).

Marketing strategies for attracting patients. The marketing strategies chosen by institutions to attract non-resident customers were identified in the data analysis. Only a third or $31.9 \%$ (95\% CI $22.3-43.3$ ) of the health care institutions surveyed listed and analysed regularly the services provided to non-residents. 66 institutions or $76.5 \%$ of the respondents (95\% CI 66.4-84.2) had a website showing the services provided; only $16.7 \%$ (95\% CI 9.8-26.9) of respondents had a specially developed long-term strategy for attracting nonresident customers. In most cases, $73.3 \%(\mathrm{n}=33)$ web sites and social networks were used to attract patients; $37.8 \%$ $(\mathrm{n}=17)$ of institutions advertised in the media, $35.6 \%(\mathrm{n}=$ 16) in specific advertising publications, $26.7 \%(\mathrm{n}=12)$ attended professional health tourism exhibitions. Intermediary marketing services were used even more rarely as a tool to attract non-resident customers. Of all respondents, $28.9 \%$ $(\mathrm{n}=13$ ) collaborated with the Health Cluster, 24.4\% ( $\mathrm{n}=$ 11) with other intermediaries in Latvia or other countries but only two medical institutions had direct collaboration with foreign clinics. 55.2\% (95\% CI 44.7-65.6) of respondents reported having average knowledge but $19.5 \%$ (95\% CI 11.1-27.8) stated they had poor knowledge of export market opportunities in healthcare. Only 14 institutions had employees who worked in international marketing.

Obstacles to promoting medical exports. Managers considered the training of specialists $(94.2 \%, \mathrm{n}=81)$ as essential to strengthen the competitiveness of the company. They also identified the modernisation of infrastructure and placing high-quality information on the website of an institution $(91.8 \%, \mathrm{n}=79)$. Identified means to boost competitiveness were: the promotion of international collaboration with medical practitioners $(90.7 \%, \mathrm{n}=78)$, the improvement of collaboration with foreign health care institutions $(85.7 \%$, $\mathrm{n}=72$ ), as well as the establishment of a legal framework for cooperation with foreign clinics $(82.6 \%, \mathrm{n}=71)$ and the signing of intergovernmental agreements on the provision of certain services $(80.2 \%, \mathrm{n}=69)$. Heads of institutions pointed out that the export of health care services would be facilitated by the development of a unified national health care export strategy $(79.5 \%, \mathrm{n}=66)$, the creation of a unified national quality system for medical institutions $(72.1 \%$, $n=62$ ) and the greater use of tourist agencies in attracting patients, as well as the liberalisation of the process to obtain visas $(69.8 \%, \mathrm{n}=60)$.

Heads of the institutions questioned also pointed to significant disruptive conditions to the promotion of medical exports. These barriers were both internal and external and
Table 2

INTERNAL AND EXTERNAL BARRIERS IDENTIFFIED BY HEADS OF INSTITUTIONS REGARDING THE PROVISIONS OF SERVICES TO NON-RESIDENT PATIENTS IN INSTITUTIONS THAT PROVIDED SERVICES AND THOSE THAT DID NOT

\begin{tabular}{|c|c|c|c|c|}
\hline \multirow{3}{*}{$\begin{array}{l}\text { Obstacles identified } \\
\text { by managers }\end{array}$} & \multicolumn{4}{|c|}{ Provision of services } \\
\hline & \multicolumn{2}{|c|}{$\begin{array}{c}\text { provided services } \\
\text { regularly }\end{array}$} & \multicolumn{2}{|c|}{$\begin{array}{c}\text { did not provide } \\
\text { services }\end{array}$} \\
\hline & $\%$ & $95 \% \mathrm{CI}$ & $\%$ & $95 \% \mathrm{CI}$ \\
\hline $\begin{array}{l}\text { Need for modernisation of the } \\
\text { infrastructure of the institution }\end{array}$ & 90.8 & $84.7-96.8$ & 88.2 & $81.4-95.0$ \\
\hline $\begin{array}{l}\text { Training and capacity building } \\
\text { of staff }\end{array}$ & 94.1 & $89.1-99.1$ & 82.4 & $74.4-90.5$ \\
\hline $\begin{array}{l}\text { Lack of interest in attracting } \\
\text { non-resident patients }\end{array}$ & 29.4 & $19.8-39$ & 70.6 & $61.0-80.2$ \\
\hline $\begin{array}{l}\text { Existing health care infrastruc- } \\
\text { ture }\end{array}$ & 53.0 & $42.5-63.6$ & 58.8 & $48.4-69.2$ \\
\hline $\begin{array}{l}\text { Operation of the health care sys- } \\
\text { tem }\end{array}$ & 58.8 & $48.4-69.2$ & 64.7 & $54.6-74.8$ \\
\hline $\begin{array}{l}\text { Regulatory framework of the } \\
\text { health care system }\end{array}$ & 47.0 & $36.5-57.6$ & 53.0 & $42.5-63.6$ \\
\hline Support structure & 76.6 & $60.9-80.2$ & 77.8 & $54.8-91.0$ \\
\hline Bureaucratic obstacles & 64.7 & $54.6-74.8$ & 76.5 & $67.5-85.5$ \\
\hline Lack of investment & 70.0 & $60.3-79.2$ & 64.7 & $54.6-74.8$ \\
\hline Social environment & 58.8 & $48.4-69.2$ & 70.6 & $61-80.2$ \\
\hline
\end{tabular}

identified both by institutions that regularly provided services to non-residents and those who did not (Table 2). Among internal barriers were mentioned the activities of the institution, such as the lack of and the effectiveness of health care staff and the inadequacy of the existing infrastructure of the institution. The most important external conditions were the lack of support structures for the promotion of exports and an amount of bureaucracy. The social environments, such as language and cultural differences, a lack of tolerance, customer service problems were also named as crucial. The odds for regular service provision to non-residents was significantly associated with the institution's internal activities, such as participation in exhibitions, knowledge of export markets, accounting and analysis of foreign patients, and a strategy for attracting foreign patients (Table 3).

\section{DISCUSSION}

The results of the study showed that medical institutions in Latvia currently treat non-resident patients and that they have an interest in developing medical exports in the future. Cross-border patient services will increase thanks to globalisation processes and Latvia needs to be aware of this. Medical tourism has also benefited from the increased mobility of individuals, low-priced airline tickets, wider availability of information because of increased technologies, a possible change of views and attitudes towards other countries and the development of the healthcare sector itself (Lunt et al. 2011).

The data obtained in the study did not enable the authors to determine the number of non-resident patients in Latvia but 
Table 3

THE ODSS RATIO FOR REGULAR SERVICE PROVISION TO NON RESIDENTS PATIENTS IN RELATION TO INTERNAL AND EXTERNAL FACTORS OF THE HEALTH CARE INSTITUTIONS

\begin{tabular}{l|c|c}
\hline \multicolumn{1}{c|}{$\begin{array}{c}\text { Factors identified by managers } \\
\text { (Yes / No) }\end{array}$} & \multicolumn{2}{c}{$\begin{array}{c}\text { Provision of regular } \\
\text { services to non-resident } \\
\text { patients (Yes / No) }\end{array}$} \\
\cline { 2 - 3 } & OR* & $95 \%$ CI \\
\hline There is an institution website & $4.9^{*}$ & $1.6-14.9$ \\
There is a strategy for attracting non-residents & $5.8^{*}$ & $1.6-21.4$ \\
There are patient / service records & $8.8^{*}$ & $2.7-28.6$ \\
Has knowledge of export market & $9.8^{*}$ & $3.0-32.2$ \\
Realizes the need for a marketing specialist & $4.2^{*}$ & $1.2-14.6$ \\
Participates in exhibitions outside Latvia & $10.2 *$ & $3.0-34.7$ \\
Participates in exhibitions in Latvia & 3.0 & $1.0-9.1$ \\
There are obstacles in regulatory framework, & 1.1 & $0.3-3.1$ \\
legislation & & \\
There are obstacles in support structures & 1.4 & $0.5-4.5$ \\
Lack of investment & 2.1 & $0.2-24.9$ \\
There are obstacles in operation of the health & 1.0 & $0.3-3.0$ \\
care system & & \\
Shortage of workforce & 0.5 & $0.2-1.6$ \\
Social environment & 0.8 & $0.3-2.2$ \\
$* p<0,05$ & & \\
\hline
\end{tabular}

verified that $19.8 \%$ of the institutions surveyed provided regular health care services to non-residents but $60.4 \%$ of institutions occasionally provided services to non-residents. The positive dynamics of the number of medical institutions registered in the Health Inspectorate working in the field of medical tourism also demonstrated an increasing interest in providing medical services for non-residents. The most common service providers for non-resident patients were those inpatient medical institutions, health centres, day care centres and dental practices with a higher number of staff and which provided complex diagnostic, treatment and rehabilitation services. Other literature also showed that non-residents were more likely to choose larger and more recognised medical institutions as well as specialist centres where more highly-skilled staff and technologies were available. The choice of location and the medical institution was also influenced by how easily information could be obtained, the services provided by the institution, the level of interest shown in the customer and the level of customer satisfaction (Anonymous, 2007; Crooks et al., 2010; Snyder et al., 2011). Research data in Latvia has shown that the interest of health care workers, especially the heads of the institutions, in providing services to foreign patients, is closely related to the provision of the services themselves. Interest is also one of the factors that determines how the availability of information regarding the institution affects the overall quality of service and care as well as the quality of the relationship between doctor and patient.

The observed relationships in the provision of regular services to non-residents in Latvia reveal similar trends to other countries. Non-resident patients undergo complex surgery, specific manipulations or rehabilitation services. The most common services are cosmetic surgery, dentistry, rehabilitation, artificial fertilisation, alternative medicine, orthopaedic services, eye surgery and they are mostly performed in inpatient medical institutions (Jesse and Kruuda, 2006; Alsharif et al., 2010; Wert and Goossens, 2010; Noree et al., 2014).

Orientation to medical tourism is evidenced by the existing strategy in some institutions to attract non-resident patients as well as the accounting and analysis of services provided. All of the institutions in Latvia that had a strategy of this kind had also provided services to non-residents, but only $68.1 \%$ of them registered and analysed customer data. Regular retrieval of information regarding customers and their strategic analysis would enable medical institutions to find the most effective methods of developing the export of services to better anticipate demand and identify areas worth developing in the future (Snyder et al., 2011).

Healthcare institutions use websites and other social networks to attract patients and provide information on potential services. They are now the most important information channels where potential customers can look for initial information regarding the options to receive faster, cheaper and better service. Social communication channels enable information to be obtained easily and transferred not only to domestic patients but also to non-residents. Institutions also place advertisements in particular publications for marketing purposes, as well as take part in exhibitions. However, they rarely have a dedicated employee in marketing in the institution. Patients tend to form informal networking groups to learn more about their choice of medical services through networks. The choice of an institution is determined by the total package offered. This includes not only the services available but also other aspects that influence choice - the corporate culture, flights and standard of accommodation. There are also additional risks to entering the medical tourism market, such as communication problems, the language barrier etc. that exist alongside medical risks - such as low quality and risks of infection (Johnston et al., 2012; Chen and Wilson, 2013; Hanefeld et al., 2015).

The results of the study point to a number of problems that need to be addressed in terms of human resources. It is obvious that staff is the key to the provision of services both to the local population and non-resident patients. A lack of quality staff threatens the quality of care and affects the corporate culture (Snyder et al., 2011). In the case of medical tourism, alongside clinical skills, a sound knowledge of marketing and managerial behaviour is needed. The quality of health care is influenced by the patient-doctor relationship, which consists of many interrelated factors, including communication, the ability of the doctor to gain the confidence of the patient, the ability of the healthcare professional to show empathy, to be tactful and honest as well as other factors (Rivers and Glover, 2008).

Generally, services to non-residents were provided by institutions whose managers knew and recognised problems such as the lack of motivation of employees, the lack of 
psycho-emotional readiness and high workload. Managers often stated the need for development of staff competences, their communication and IT skills, but the lack of professional and foreign language skills were less frequently identified. Recruitment difficulties were emphasised more by heads of institutions that did not provide services to nonresidents. Some consider that the brain drain of local talent into private, not-for-profit organisations focused on nonresident care can explain this (Chanda, 2002). There are examples of other countries that have developed guidelines as a national standard for the provision of culturally and linguistically competent services. These standards can also provide organisational support for the training of cultural competences (Branch and Fraser, 2002).

The study revealed the general opinion of the heads of institutions regarding the main obstacles to the promotion of medical exports in Latvia. All institutions have observed obstacles to the functioning of the health care system, health care legislation or health care staff. However, respondents who did not provide services to non-residents or only provided them occasionally indicated these obstacles proportionally higher than those who provided services regularly. It is possible that institutions that provided services to foreign patients on a regular basis were more successful in dealing with specific problems. However, institutions that provided regular services to non-resident patients often stated that the lack of investment in the development of new healthcare services was an obstacle. Respondents expressed the view that the most important measures to promote medical tourism were the training of staff, the modernisation of infrastructure, information on the website of the institution and the promotion of international collaboration with medical practitioners. Some individuals said that supportive measures at a national level were needed to increase the flow of medical tourism; this, in turn, could be beneficial at a national level.

Medical tourism mega-cities are emerging in the world; for example, cities such as Singapore and Dubai. These cities provide first class medical tourism services as part of the development strategy of the cities and countries. For example, the establishment of the Dubai Health Care City aims to attract medical tourists from the Middle East and prevent tourists from travelling to Asia. Singapore has expanded its activities in the field of biomedical and biotechnology since 2001. Networks of health care institutions have been established in Turkey and India, involving several internationally-accredited hospitals (Crone, 2008; Lunt et al., 2011). This development is possible with the support of a national policy for medical tourism. It is generally accepted that support for medical exports needs to be provided by various export support agencies or companies. These companies are usually used by those who already export medical services. In order to promote the export of health care services, more information and knowledge on export opportunities for foreign markets are needed. Consultations, support, advice, credit facilitation and assistance with procedural issues are needed to help a company make a decision regarding the setting up of export services (Johnston et al., 2012).

Medical tourism is also a way of generating profit for an institution. It has been found in Canada, for example, that restrictions on private medicine interfere with the development of medical tourism and more medical tourists are attracted by countries with a wider network of private medical institutions. However, countries that attract many medical tourists may also experience an increase in prices in the local market and a shift from providing services to their own residents (Johnston et al., 2010; Hall, 2011; Hanefend et al., 2013).

Medical tourism affects the health systems of both importing and exporting countries. In the case of medical tourism, multifaceted relationships between the customer and the national healthcare system of another country and its medical treatment institution have to be formed as a consequence. It has been shown that the impact can be reciprocal, the development of medical tourism can influence the processes of development of the national health care system and its institutions while the more developed systems and high-quality services can attract non-resident customers (Beland and Zarzeczny, 2018). The development of the supply side will contribute to a better understanding of the problems of systems and institutions that need to be addressed to increase the competitiveness of healthcare in an international setting. A previous analysis of medical tourism showed the strength of the health care industry, the problems associated with the supply and promotion of medical tourism products as well as emphasised the debate on medical tourism policy and its future (Neil et al., 2013). A number of publications have shown that the scientific community has an interest in discovering which health policy issues need to be addressed by health care systems that want to enter or develop medical tourism (Johnston et al., 2010; Hanefeld et al., 2014). Health care systems across countries vary widely and are considered as relatively stable systems that can affect the behaviour of people. The decision whether a person will cross a border to receive the necessary health care service will be affected by the health care system in his/her own country, its coverage, funding, regulatory framework as well as costs, quality and waiting times (Busmante, 2014). Not only are there differences in national health care systems but there are also differences in their institutional characteristics, which also affect the flow of medical tourists (Beland and Zarzeczny, 2018).

The conducted analysis revealed a number of methodological problems that may affect the results obtained. Firstly, the low level of response and the low number of respondents. Consequently, the trends and relationships found in the data analysis are not statistically significant. This prevents general conclusions being made, but permits forming an idea of the main trends. The heads of institutions who completed the questionnaires are likely to represent the institutions that are more involved and interested in providing services to non-residents. This study did not allow the authors to define what a group of non-resident patients is - 
medical tourists who have arrived in Latvia with the aim of receiving medical treatment or the recipients of occasional services. Assistance to non-residents in Latvia is provided both within the framework of a cross-border directive and in emergency situations. The respondents of this survey were the heads of institutions and thus reflected their opinion rather than the opinion of wider health professionals.

Therefore, there is a need for further research to ascertain both the prevalence of medical tourism in Latvia and the factors characterising non-resident patients, services they use, as well as the factors that affect their decision to choose to receive the service in Latvia and the satisfaction with the health care received. Obtaining a better understanding of the complex relationships between a patient, the health care institution and service provision can promote the creation of new opportunities for medical tourism.

\section{CONCLUSION}

The results of the study showed the medical institutions were more likely to provide services to non-resident patients when the administrative staff and doctors were more interested in providing them. Managers whose institutions treated non-resident patients identified and dealt with staff problems more frequently than others. The factors of internal policy of the medical institution and the state policy were more important in attracting regular non-resident patients than factors characterising the social environment and human resources. The factors of internal policies of the institution identified as important in the provision of services to non-residents were: knowledge of the export markets, accounting of the services provided and participation in exhibitions. Significant factors of state policy regarding the provision of services to non-residents were: access to investment, health care legislation and support structures.

\section{ACKNOWLEDGEMENTS}

This study was supported by the National Research Programme 5.2. "Economic Transformation, Smart Growth, Governance and Legal Framework for the State and Society for Sustainable Development - a New Approach to the Creation of a Sustainable Learning Community (EKOSOC-LV)".

The authors are grateful to administrators of health care institutions who participated in the study.

\section{REFERENCES}

Adlung, R., Carzaniga, A. (2001). Health services under the General Agreement on Trade in Services. Bull. World Health Organiz., 79, 352-364.

Alsharif, M. J., Labonté, R., Lu, Z. (2010). Patients beyond borders: A study of medical tourists in four countries. Global Soc. Pol., 10 (3), 315-335.

Anonymous (2007). Cross-border health services in the EU. Analytical report. Flash Eurobarometer Series $N^{\circ} 210$. Hungary: The Gallup Organization, 2007. $42 \mathrm{pp}$.

Anonymous (2011). Directive 2011/24/EU of the European Parlament and of the Council of 9 March 2011 on the application of patients' rights in cross-border healthcare. Available from: http://eur-lex.europa.eu/legalcontent/LV/ALL/?uri=CELEX:32011L0024 (accessed 20 December 2018).

Anonymous (2014). Health at a Glance: Europe. OECD Publishing, Paris. 131 pp. Available from:

http://dx.doi.org/10.1787/health_glance_eur-2014-en (accessed 20 November 2018).

Anonymous (2018). Ārstniecības iestādes, kas reǵistrējušās medicīnas tūrisma pakalpojumu sniegšanai [Medical Institutions registered for providing of medical tourism services]. The Health Inspectorate. Available from:

http://www.vi.gov.lv/uploads/files/medicinas\%20turisms_03042018(1).pdf (accessed 10 December 2018).

Béland, D., Zarzeczny, A. (2018). Medical tourism and national health care systems: an institutionalist research agenda. Global Health, 14 (1), 68.

Bustamante, A. (2014). Globalization and medical tourism: The north American experience. Int. J. Health Pol. Manag., 3 (1), 47-49.

Brach, C., Fraser, I. (2002). Reducing disparities through culturally competent health care: An analysis of the business case. Qual. Manag. Health Care, 10 (4), 15-28.

Carrera, P. M., Bridges, J. F. P. (2006). Globalization and healthcare: Understanding health and medical tourism. Expert Rev. Pharmacoecon. Outcomes Res., 6 (4), 447-454.

Chen, L. H., Wilson, M. E. (2013). The globalization of health care: Implications of medical tourism for the ID clinician. Clin. Infect. Dis., 57 (12), $1753-1759$.

Crone, R. K. (2008). Flat medicine? Exploring trends in the globalization of health care. Acad. Med., 83 (2), 116-121.

Crooks, V. A., Kingsbury, P., Snyder, J., Johnston, R. (2010). What is known about the patient's experience of medical tourism? A scoping review. BMC Health Services Res., 10, 266-277.

Hall, C. (2011). Health and medical tourism: A kill or cure for global public health? Tourism Rev., 66 (1/2), 4-15.

Han, H., Hwang, J. (2018). Growing competition in the healthcare tourism market and customer retention in medical clinics: New and experienced travellers. Curr. Issues Tour., 21, 6, 680-702.

Hanefeld, J., Lunt, N., Smith, R., Horsfall, D. (2015). Why do medical tourists travel to where they do? The role of networks in determining medical travel. Soc. Sci. Med., 124, 356-363.

Hanefeld, J., Horsfall, D., Lunt, N., Smith, R. (2013). Medical tourism: A cost or benefit to the NHS? PLoS One, 8 (10), e70406.

Hanefeld, J., Smith, R., Horsfall, D., Lunt, N. (2014). What do we know about medical tourism? A review of the literature with discussion of its implications for the UK National Health Service as an example of a public health care system. J. Travel Med., 21 (6), 410-417.

Horowitz, M. D., Rosensweig, J. A. (2007). Medical tourism: Health care in the global economy. Physician Exec., 33 (6), 24-30.

Jesse, M., Kruuda, R. (2006). Cross-border care in the north: Estonia, Finland and Latvia. In: Rosenmöller, M., McKee, M., Baeten, R. (Eds.). Patient Mobility in the European Union. Learning from experience. European Observatory on Health Systems and Policies, Copenhagen, pp. 23-37.

Johnston, R., Crooks, VA, Snyder, J. (2012). “I didn't even know what I was looking for": A qualitative study of the decision-making processes of Canadian medical tourists. Globalization and Health, 8, 23.

Johnston, R., Crooks, V. A., Snyder, J., Kingsbury, P. (2010). What is known about the effects of medical tourism in destination and departure countries? A scoping review. Int. J. Equity Health, 9, 24.

Lautier, M. (2014). International trade of health services: Global trends and local impact. Health Policy, 118 (1), 105-113.

Lee, C. (2007). Medical tourism, an innovative opportunity for entrepreneurs. J. Asia Entrepreneur. Sustain., 3 (1), 1-12. 
Lee, M., Han, H., Lockyer, T. (2012). Medical tourism - Attracting Japanese tourists for medical tourism experience. J. Travel Tour. Market., 29 (1), 69-86

Lunt, N., Carrera, P. (2011). Systematic review of web sites for prospective medical tourists. Tourism Rev., 66 (1/2), 57-67.

Lunt, N. T., Mannion, R., Exworthy, M. (2013). A framework for exploring the policy implications of UK medical tourism and international patient flows. Social Policy Admin., 47 (1), 1-25.

Lunt, N., Smith, R., Exworthy, M., Green, S. T., Horsfall, D., Mannion, R. (2011). Medical Tourism: Treatments, Markets and Health System Implications: a scoping review. Organisation for Economic Co-operation and Development, Paris. 55 pp.

Mattoo, A., Rathindran R. (2006). How health insurance inhibits trade in health care. Health Aff (Millwood), 25 (2), 358-368.

Noree, T., Hanefeld, J., Smith, R. (2014). UK medical tourists in Thailand: They are not who you think they are. Globaliz. Health, 10 (1), 29-35.

Ormond, M., Sulianti, D. (2017). More than medical tourism: Lessons from Indonesia and Malaysia on South-South intra-regional medical travel. Curr. Issues Tour., 20 (1), 94-110.
Počs, R., Ozolina, V. (2016). Latvijas ekonomikas konkurētspējas izpētes instrumentārijs [Instrumentary for competitiveness analyses of the Latvian economy]. Latvijas Zinātṇu Akadēmijas Vēstis, A daḷa, 70 (3), 10-19 (in Latvian).

Rivers, P. A., Glover, S. H. (2008). Health care competition, strategic mission, and patient satisfaction: Research model and propositions. J. Health Organiz. Manag., 22 (6), 627-641.

Singh, N. (2013). Exploring the factors influencing the travel motivations of US medical tourists. Curr. Issues Tour., 16 (5), 436-454.

Shenfield, F., de Mouzon, J., Pennings, G., Ferraretti, A. P., Nyboe Andersen A., de Wert G., Goossens, V. (2010). Cross border reproductive care in six European countries. Human Reprod., 25 (6), 1361-1368.

Snyder, J., Crooks, V. A., Johnston, R., Kingsbury, P. (2011). What do we know about Canadian involvement in medical tourism? A scoping review. Open Med., 5 (3), e139-e148.

Timmermans, K. (2003). Developing countries and trade in health services: Which way is forward? Int. J. Health Serv., 34 (3): 453-466.

Wang, H. Y. (2012). Value as a medical tourism driver. Man. Serv. Qual., 22 (5), 465-491.

Received 18 January 2019

Accepted in the final form 4 June 2019

\section{FAKTORI, KAS NOSAKA KONKURĒTSPĒJU VESELĪBAS APRŪPES IESTĀDĒS LATVIJĀ — EKOSOC-LV VALSTS PĒTİJUMU PROGRAMMA}

Konkurētspēja kā uzṇēmuma spēja pārdot savus pakalpojumus tirgū kḷūst aizvien aktuālāka arī veselības aprūpes jomā. Medicīnas tūrisms visā pasaulē ieṇem nozīmīgāku globālās ekonomikas daḷu. Pieaug valstu un iestāžu skaits, kuras savus pakalpojumus vēlas piedāvāt starptautiskajiem pacientiem. Zinātniskā izpēte liecina, ka medicīnas tūrisma attīstība ir valstu specifiska. Pētījumi atklāj, kādi faktori ietekmē pacienta izvēli doties sanemt pakalpojumu uz citu valsti. Mazāk ir pētīts veselības aprūpes pakalpojumu sniedzēju vērtējums par veicinošiem un bremzējošiem faktoriem iesaistîties pakalpojumu sniegšanā ārvalstniekiem, kas ir šīs publikācijas galvenais mērkis. Dati iegūti šḳērsgriezuma pētījumā, kurā piedalījās un anonīmi aptaujas anketu aizpildīja 86 veselības aprūpes iestāžu vadītāji Latvijā. Kopumā 80,2\% no veselības aprūpes iestādēm iepriekšējā gadā sniegušas pakalpojumus ārvalstu pacientiem, bet 19,8\% to darījušas regulāri. Biežāk pakalpojumus sniegušas iestādes ar lielāku darbinieku skaitu, kuras atrodas galvaspilsētā. Savu pakalpojumu reklamēšanai iestādes izmanto mājaslapu, mazāk speciālos izdevumus, dalību izstādēs. Tikai atsevišķām iestādēm ir algots mārketinga speciālists, izstrādāta stratēǵija ārvalstu pacientu piesaistei un notiek klientu un pakalpojumu analīze. Iestāžu vadītāji norāda vairākus iekšējus un ārējus šḳēršlıs, kas ietekmē konkurētspēju, kā personāla trūkums, zemā motivācija, valodas zināšanas, neatbilstoša infrastruktūra, nepietiekams valstiska līmeņa atbalsts pakalpojumu eksporta veicināšanai, sociālā vide, nesakārtotība veselības aprūpes sistēmā. Pētījums atklāj darbības jomas nākotnes politikas un prakses uzlabošanai ārvalstu pacientu piesaistē un globālās konkurētspējas veicināšanai. 